\title{
Music Performance Policy during Covid-19 Crisis: Expectations Versus Reality
}

\author{
Riyan Hidayatullah \\ Music Education Study Program, Universitas Lampung, Indonesia \\ E-mail: riyan.1002@fkip.unila.ac.id \\ Received: March 11, 2021 Accepted: May 8, 2021 Online Published: May 17, 2021.
}

\begin{abstract}
This paper examines public discourse on web pages and social media as a form of digital ethnography during the COVID-19 crisis. During the "lockdown" in Indonesia, internet traffic increased, creating new habits for performance music. A total of 657 tweets, YouTube talk shows, and online news pages were analyzed using NVIVO12. The data was taken using 'Ncapture,' 'Word Frequency,' and 'Sociogram Analysis. Each keyword was analyzed as a representation of a particular musical problem during the pandemic. The goal is to identify differences between government policies and their implementation. Online activities explore a variety of things about music during the pandemic. The conversation continued with the awareness that the musicians would be offering their peers. Collective sentiments were more stressed during the COVID-19 crisis, giving rise to social unity. The theory of cooperation between music workers is a solution that can be implemented
\end{abstract}

Keywords: Music performance, policy, covid-19, digital ethnography

\section{Introduction}

After the first case announced in Indonesia by President Jokowi, all groups were paralyzed (The Jakarta Post, 2020). The whole world has been busy with the COVID-19 virus in the last year or so. The rise in the number of cases in Indonesia until March 32021 is about 6,389, which means that the number of people infected is 1,392,945 (Kompas.com, 2021). All aspects of natural life are affected, from health, economy, education, political life to music. All the elements of society have been moving to survive. Furthermore, unfortunately, some of them cannot continue to subsist. Today, everyone's eyes are focused on promoting recovery and economics. During the quarantine, all activities, including work, are carried out at home. Usually, people do things simultaneously when listening to music they like on Spotify or YouTube. There is not anything that can be done to make musicians and teachers perform as usual. All of their activities involve physical encounters and direct communication. This condition contributed to the idea of seeking a new standard for musical life.

Almost every performance has improved, start with production, practice, learning, and live music. There is no ideal recipe for the present situation because everyone is still looking for a new reality. Teachers and musicians have two choices to use the old method or switch directly to the virtual world. Teachers use remote learning to manipulate their band classes (Hash, 2021). Distance music education during the COVID-19 crisis encourages the expansion of internet access, emphasizes the individual, improves knowledge of music theory and history, and guides students to make music creatively. In reality, the students' interpersonal relationships were affected significantly. They will be able to perform again after experiencing a lockdown (Antonini Philippe, Schiavio, \& Biasutti, 2020). Music education is at the intersection of funding, policies, and equity for student access (Savage, 2021). COVID-19 also played a significant role worldwide for singers and other artists (Vance, Shah, \& Sataloff, 2021). This kind of musical operation becomes deadly if anyone neglects the use of masks, does not wash your face, and keeps your distance away. Physical contact and regular interactions are common in all musical activities. Exercise has been found to have a more positive effect than music rehearsal (Habe, Biasutti, \& Kajtna, 2021). This finding has a positive impact on the musical ecosystem's overall wellbeing. People choose their health over other desires, such as music. 
The shift from physical to digital interaction also opens up new concepts for music organizers. For example, through streaming concerts on social media, some also try out extreme styles, such as drive-in concerts, which were first held in Semarang, Central Java, Indonesia (Metro TV Jateng \& DIY, 2020; Riyan Hidayat, 2020). Another event of a balcony concert performed in Miami captured the attention of the residents who were occupying luxurious apartments at the time (David Guetta, 2020). Usually, musical performances had taken place before COVID-19. In Indonesia, a music player in a cafe can support the needs of his family. Concerts that take place require daily practice; require close physical experiences and interactions. After this situation had changed, and some physical distances had been made, all musical practices seemed halted and chaotic. Owing to different laws prohibiting crowds, musicians can no longer express themselves. There is no longer any connection between the audience and the performer, such as live music, usually filled with guests. This condition is threatening the life and nature of the musicians.

Jatmika (2020) reported that there are essential things that cannot be replaced by physical concerts. Parsons (2020) also acknowledges that certain significant items are missing from virtual music performances. People refuse to go online and spend a lot of time; nonetheless, the multi-track arrangement has always existed on the other side (in the context of player and organizer). Physical music experiences are very significant manifested as a means of increasing collective feeling. New musical activity via streaming $/ s c a n$ brings up old and new rituals in online communities (Vandenberg, Berghman, \& Schaap, 2021). However, it is a certainty in the modern average age of music. The modern habit of performing music through live remaining also poses the skeptical question: will physical concerts be just as good as virtual concerts? Alternatively, even introducing a new concept in the sense of live music (Sahid, 2020).

The population of HORECA musicians (hotels, cafes, and restaurants) is $34.3 \%$. This figure is the most significant number of session beaters (12.9\%) and teachers (10.1 percent ). The data were taken from the results of the FESMI survey of 1,400 respondents. FESMI is a federation of Indonesian musicians who have been founded to help the government solve the social problems of musicians (Riyan Hidayat, 2020). There has been no discussion of policy concerns specific to musical performances of the different realities that occur in relation to COVID-19. The discussions that have taken place so far have only been in the community of artists or musicians. FESMI focuses on four topics, including providing instruction and information to artists, protecting the health, and ensuring prosperity, as a hub for information on music-related issues, and media for contact between music workers. While this federation has been established with a good vision, the policy discourse needs to be addressed. The goal is to make the government aware of the importance of music to the contribution of the country's creative industry and tourism. Persuasive approaches need to be applied in a variety of more exciting ways, such as musical works that contain messages of kindness regarding COVID-19 (Lehman, 2020). This article examines Indonesia's musical performance strategy during the COVID-19 crisis. According to the most recent news reports, there is no literature on musical performance policy issues during the pandemic. As a result, the writers plan to provide preliminary data to the government in order for it to assess music policy in the aftermath of the COVID-19 crisis.

\section{Method}

This study uses digital ethnography to explore some facts and concepts found in big data format. The internet has become a part of human life, and most activities are carried out there (Hine, 2015). This approach aims to investigate the culture and objects of digital or virtual musical practices. Interactions that take place online via social media are used as a replacement for fieldwork. Various issues that appear on websites, blogs, twitter, and YouTube channels are valuable data for starting cyber ethnography. Complementing this digital-based research approach is simple, thanks to social media, videotapes, websites, blogs, and other internet features. While Barendregt (2017) had doubted the depth and the holistic method of this approach, Hine closed it humanely, particularly with the adaptability that new methods have always had. Postill (2017) maintains that digital media completeness can forecast researchers' intimate fieldwork; it fully supports the systematic manner in which data can be examinedexamined. The ethnographic paradigm is still used to display cyberspace life maps so that the meaning of the particular technique does not remain. The authors consider aspects of expertise and access to digital versions of fieldwork (Addeo, Delli Paoli, Esposito, \& Ylenia Bolcato, 2019) and continue concentrating on social activities in the respondents' daily life (Kozinets, 2015).

Data analysis uses NVIVO12 features such as 'word frequency' and 'word cloud' to check for keywords commonly discussed in cyberspace. This function is used to analyze data or knowledge as a preliminary collection of data (Bazeley \& Jackson, 2013, p. 110). The aim is to find new or surprising ideas to be used as a research idea or proposal. This move is an examination of a particular discourse that leads to more critical and 
complex problems of the same nature. Then categorize keywords and search for associated relationships. The next step were to focus on the relationship between the keywords. The final stage concludes the use of the related literature to interpret each result. 'Ncapture' is used to evaluate conversations and interactions on web pages and Twitter. Responses to the National Music Day were observed using hashtags related to music and the pandemic (specifically targeting Indonesian users). These thoughts are used through reflection to conclude.

\section{Results}

It was discovered which keywords were listed the most in digital search data from many online news outlets. The main word below is often used in news headlines and television discussions. The following are also closely linked to the life of musical performances in Indonesia. Owing to health concerns, live music is not recommended. Several musical performances were required to be cancelled because they violated federal policy on health protocols. Although it is not frequently discussed, economic issues are frequently used as an excuse by the government to enforce the COVID-19 crisis strategy (see: table 1).

Definition 'length' means the number of words in one sentence; 'count' means the number of words in all data sources (webpage). "Length" was used to see the degree of the term used in the form of a specific sentence. This term underlines that the keyword is more appealing to people talking about it. The terms 'Indonesia' (9), 'covid' (5) and 'Jakarta' (7) reflect the meaning of the debate being addressed. 'Health' (6), 'music' (5), and 'live' (4). The highest conversations occurred in the terms 'entertainment' (13), 'coronavirus' (11),' rescheduled '(11),' 'restaurants' (11). These keywords continue to demonstrate that the existence of COVID-19 influences the physical activity of music. Musicians playing in hotels, restaurants, and cafes are entertainment industry players who have missed many gig schedules. In general, there are two choices between their work to be terminated or the event to be postponed indefinitely. The results of the data search are based on the background of Indonesia.

Table 1 . Word frequency query result

\begin{tabular}{|c|c|c|c|}
\hline Word & Length & Count & Weighted Percentage (\%) \\
\hline Indonesia & 9 & 60 & 1.70 \\
\hline Jakarta & 7 & 43 & 1.22 \\
\hline Covid & 5 & 41 & 1.16 \\
\hline Live & 4 & 29 & 0.82 \\
\hline Health & 6 & 28 & 0.79 \\
\hline Music & 5 & 27 & 0.76 \\
\hline Concert & 7 & 25 & 0.71 \\
\hline Festival & 8 & 18 & 0.51 \\
\hline March & 5 & 18 & 0.51 \\
\hline Cases & 5 & 17 & 0.48 \\
\hline Pandemic & 8 & 17 & 0.48 \\
\hline Artists & 7 & 15 & 0.42 \\
\hline Allowed & 7 & 14 & 0.40 \\
\hline Coronavirus & 11 & 13 & 0.37 \\
\hline Postponed & 9 & 13 & 0.37 \\
\hline Events & 6 & 12 & 0.34 \\
\hline Musicians & 9 & 12 & 0.34 \\
\hline Tourism & 7 & 12 & 0.34 \\
\hline Rescheduled & 11 & 11 & 0.31 \\
\hline Protocols & 9 & 10 & 0.28 \\
\hline Restaurants & 11 & 9 & 0.25 \\
\hline Entertainment & 13 & 8 & 0.23 \\
\hline Social & 6 & 8 & 0.23 \\
\hline
\end{tabular}




\begin{tabular}{llll}
\hline Tickets & 7 & 8 & 0.23 \\
\hline Economy & 7 & 7 & 0.20 \\
\hline
\end{tabular}

The closure of entertainment venues has impacted local and international tourism (like restaurants, hotels, and cafes). Although some practices are carried out according to strict health guidelines, there are still rules and frequency of musical performances. Social and physical limitations limit the number of visitors. Ticket sales in music concerts dropped dramatically. This fact influences fans, in particular local artists, to contribute financially to entertainment entrepreneurs.

Policy

The government of Indonesia enforced policies governing social and physical constraints during the COVID-19 crisis. The longevity of music performances in the entertainment industry is affected (See figure 1). The tourism sector has a devastating impact because the economy depends on entertainment programs involving music. There are few cafés or restaurants, but with some requirements, musicians may play. Carry a mask, keep a safe distance, control the body temperature, frequently have to wash your hands, and recommend that you not leave the house cold (Cabinet Secretariat of The Republik of Indonesia, 2020; The Jakarta Post, 2020b). This campaign continues with the creation of other health, transport, and economic recovery policies. The activities of an artist or musician in musical performances consist of two things-first, music production, which is done with physical activity. Before orchestral groups do concerts or recitals, they generally do regular rehearsals. The ensemble (group) involves many members with a friendly crowd. Group exercise is an irreplaceable activity because it requires the blending of sounds and harmony in real-time (Michael Mulyadi, 2020).

The artistic activities of the players in the music sector continue to be limited. The music industry players display a reasonably robust attitude at this stage. The only medium to continue producing is the use of digital channels. Both as a platform for new music and a medium for live streaming performances. These efforts can be a temporary solution during a pandemic as an alternate medium. The government's strategy of vaccine delivery, which started last January, has been a breath of fresh air in the treatment of Covid-19 (Kumparan, 2021). This will give the Indonesian people herd immunity while maintaining strict and disciplined health protocols. The post-vaccine program for the Indonesian citizens is expected to reestablish the situation in all industries, including the music market. In this context, policy preparation for the post-Covid music industry is essential. Concerts and music festivals have been massively delayed after the President revealed them in early March 2020. Suddenly, the film industry collapsed. Furthermore, the government is concerned about the health and social problems. The residents ignored the advice to use masks and resume their daily work. They have no options for hotels, café, and restaurant musicians. Unfortunately, their income depends on their results.

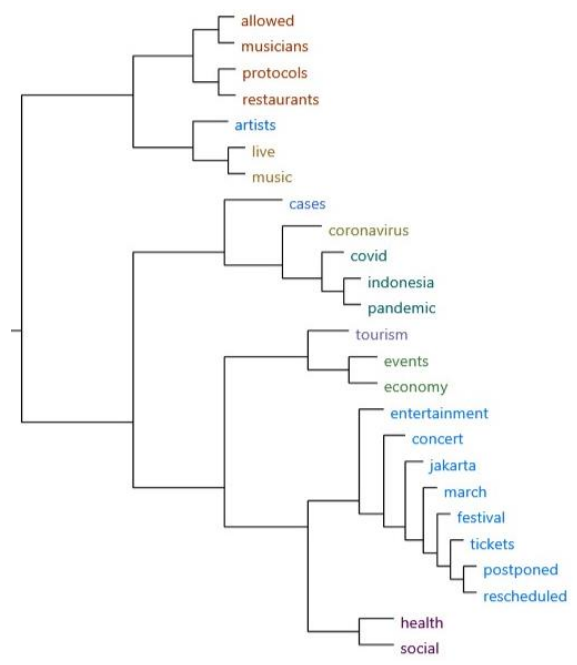

Figure 2. Cluster analysis on live music during COVID-19

Regarding the latest data published by the Creative Economic Agency (Bekraf) in 2016, Indonesia's music industry's contribution is less than $1 \%$, just 0.46 percent. Not a few sectors use music like restaurants, hotels, tourist centers, and other public spaces. It means that the management of the music industry in Indonesia has 
issues. There is also a range of legal instruments that can be used to regulate the music industry in Indonesia. Beginning with the Cultural Advancement Law No. 5 of 2017, which deals specifically with collecting data in the cultural aspect of which music is a field. The result is the need for the presence of extensive data in the music industry.

Furthermore, there are still issues with Law No. 28/2014 on copyright in terms of interpretation, enforcement, and derivative control. Not to mention how this is juxtaposed with the recent heavy use of digital in the music industry. In terms of the music industry, the government must present these diverse challenges with a great perspective, especially after a year Indonesia was hit by Covid-19, which significantly impacted this industry. The need to prepare the post-Covid music industry is here. However, since the Covid-19 pandemic struck in 2011, the government has not produced a strategy that has a structuring effect on this sector, the Ministry of Tourism and Creative Economic. The Creative Economic Agency's role in President Jokowi's 2014-2019 administration should be a landmark in organizing the sector by the Ministry of Tourism and Creative Economic (Detiknews, 2021).

Live music concerts and musical events are not governed by any particular policy. Laws that have so far been laid down separately; one governs individual musicians as citizens; the other sets up entrepreneurs to enforce working hours and manage crowds. A different approach has been adopted for the art staff impacted by COVID19. There are a number of conditions for an artist to be considered for financial assistance (Antara News, 2020). Grant recipients are split into two groups based on their priority. First, cultural workers who are married and do not have other employment. Second, those who are not married and have a higher income than the first (Kemdikbud, 2020).

\section{Discussion}

On the occasion of National Music Day on March 9, 2021, the Directorate General of Culture's Twitter account, especially the Directorate of Music Films and New Media, has become a topic of discussion. Thousands of accounts discuss his worry, fear, longing, hope, prayer, and support for better governance in Indonesian music. The debate was sparked by a live broadcast of the 'Budaya Saya' channel, which featured influential figures as resource persons. The preservation of traditional music is another subject worth debating (Budaya Saya, 2021). The number of works and local musicians that are not yet widely available. The establishment of a special institution to handle data on musicians, works, musical instruments, pay standards, and other topics was also suggested during the discussion. Traditional music must be safeguarded in a methodical and prepared manner. Musical success is not limited to the Western music industry. Traditional music is another aspect of the show that deserves further exposure.

Along with the National Day of Music on March 9 2021, the expression of the virtual world community represents their thoughts on the COVID-19 crisis. Social movements have begun to aid musicians affected by the pandemic. Musicians donate their guitars to help the music crew continue their lives. Indonesians pity their fellow musicians on Twitter. The 'HailMagazine' account was retweeted by a fundraiser musician (Noel) who sold his guitar for charity. Events on the music day may also encourage musicians to focus on the pandemic condition (See: figure 3). The positive results of COVID-19 encourage musicians to support their peers (Septiyan, 2020).

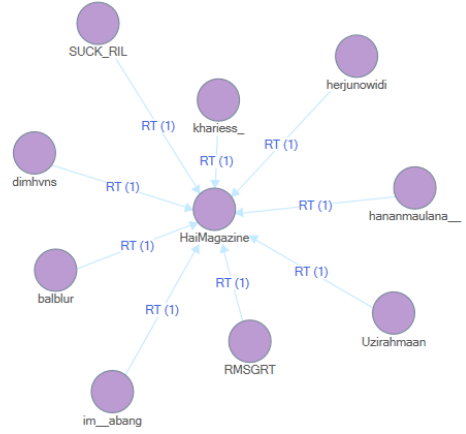

Figure 3. Twitter sociogram

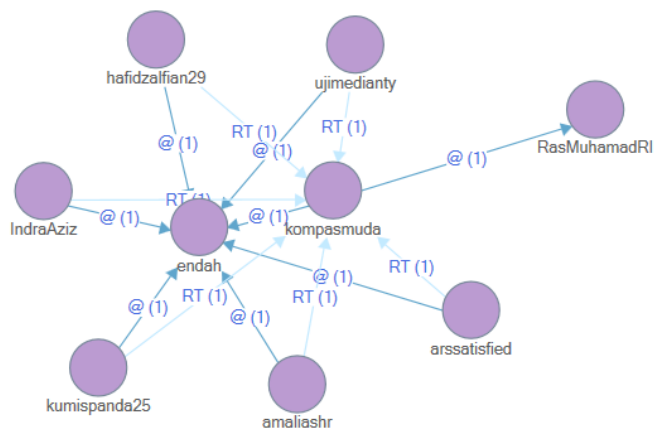

Figure 4. Twitter sociogram

A musician named 'Endah' showed his feelings about the noise and atmosphere of the concert. If the crisis of COVID-19 persists, Indonesia's music industry will eventually die. They have given hope and a long time to physical music practices. The emergence of digital music concerts at this time has not yet addressed the 
musicians' urge to perform music on stage. The statement was retweeted by six people who were anxious about the same musical performance (See figure 4).

Each twitter account is usually based on musical experience or comes from a musician's circle. They give a glimpse of the virtual display, which has numerous flaws. The artists, on the other hand, are still working and expressing their imagination through their songs. Multiple'retweets' of accounts continue to boost productivity. Indra Aziz said on his Twitter account that becoming a musician is a profession that must be fought for. Musicians must create wealth in order for their musical works to continue to be made. Furthermore, professional musicians are gradually being regarded as members of other professions. The drop in musicians' earnings during the COVID-19 crisis exacerbated the slump in music. Many people are concerned that the energy of this music day has been used as a catalyst for the establishment of some musical institutions.

A further reflection focuses on the essence of musical performances that emphasize two-way contact. The artistaudience relationship is going to have a different experience when it's kept virtually (Jatmika, 2020). Jatmika went on to say that the encounter between musicians and audiences is a highly emotional musical experience. The environment is a vital part of music, but it cannot be removed. Appreciating live music is a part of being satisfied, and the audio quality is often different (Septiyan, 2020). Buying an album is the art of waiting for the artist to perform a concert for music fans. They create closeness through songs that are normally heard on mp3, and it's time for the concert to arrive when emotions are overflowing and fulfilled. Seeing his favorite artists perform in front of a live audience of loud voices, stage acts, and flawless communication made him even more perfect. It is not without difficulties that one million rupiahs are distributed in funds. The procedure is thought to take a long time, and musicians will face some new issues, such as personal data and artwork authenticity. The pandemic could not repay the money spent on physical concerts. Also, the proceeds of digital concerts did not offset the revenues created by the music production team. Like a domino effect, this pattern continues to repeat itself.

In order to welcome the next virtual music world, various elements, beginning with the community, artists, government, and investors, must work together. All of them must contribute to the development of a new formula for overcoming the COVID-19 crisis, especially for musicians. As audiences have migrated online, many performance spaces have grown to meet their needs. Additional cameras were mounted throughout the concert hall and stage to provide audiences with a familiar yet unique experience. Every musicians are looking forward to the pandemic's artistic legacy of live music results.

\section{Conclusion}

The Indonesian government has not yet concentrated on musical events, as all funds are geared towards health and economic recovery. But that doesn't understate music; policies can be developed with the music community's input, including researchers and academics. Through long and comprehensive debates, theoretical issues have been addressed and become a contributor to the government's support in supporting musicians with social problems. Collaboration between the elements needs to be encouraged as a short-and long-term solution. Besides HORECA musicians, local (traditional) musicians also need more focus. They cannot find any other income and depend solely on government policies. The theory of teamwork assists their needs, such as the migration of physical output to the internet. Digital technology skills for local musicians are also missing. Creative staff with video editing abilities, recording music, producing content will at least help them embrace a new standard musical performance.

Some people also digitally consume music. For music to have a selling value during the COVID-19 crisis, the material must be meaningful and can be consumed by several people. HORECA and local artists need to be supported in terms of expertise so that they can compete with major names or professional companies. People need to be encouraged to continue to enjoy music and increase their awareness of giving. Policies may take the form of old guidelines that have been tightened up by health protocols or new points that concentrate on musician issues. Legal certainty is what artists need to be survived.

\section{Acknowledgemnt}

Many thanks are extended to all those who took part in the research. Of course, I also thank experts for their sage and innovative guidance that has aided me in refining this work. I encourage both parties to make valuable knowledge available for further study. As a result, this digital ethnography method can be further developed. 


\section{References}

Addeo, F., Delli Paoli, A., Esposito, M., \& Ylenia Bolcato, M. (2019). Doing social research on online communities: The benefits of netnography. Athens Journal of Social Sciences, 7(1), 9-38. Retrieved from https://doi.org/10.30958/ajss.7-1-1

Antara News. (2020). Bantuan untuk pekerja seni terdampak COVID-19 lewat PKH [Webpage]. Retrieved 10 March 2021, from https://www.antaranews.com/berita/1406258/bantuan-untuk-pekerja-seniterdampak-covid-19-lewat-pkh

Antonini Philippe, R., Schiavio, A., \& Biasutti, M. (2020). Adaptation and destabilization of interpersonal relationships in sport and music during the Covid-19 lockdown. Heliyon, 6(10), e05212. Retrieved from https://doi.org/10.1016/j.heliyon.2020.e05212

Barendregt, B. (2017). Deep hanging out in the age of the digital; contemporary ways of doing online and offline ethnography. Asiascape: Digital Asia, 4(3), 307-315. Retrieved from https://doi.org/10.1163/22142312-12340082

Bazeley, P., \& Jackson, K. (2013). Qualitative data analysis with NVivo (Second edition). Los Angeles London New Delhi: SAGE.

Budaya Saya. (2021). Hari musik nasional [YouTube Channel]. Retrieved 19 March 2021, from https://www.youtube.com/watch?v=s-YIp6EgFVs

Cabinet Secretariat of The Republik of Indonesia. (2020). Gov't to Intensify 3M Campaign to Curb COVID-19 Family Cluster [Webpage]. Retrieved 10 March 2021, from https://setkab.go.id/en/govt-to-intensify3m-campaign-to-curb-covid-19-family-cluster/

David Guetta. (2020). David Guetta | United at Home - Fundraising Live from Miami \#UnitedatHome \#StayHome \#WithMe [YouTube Channel]. Retrieved 9 March 2021, from https://www.youtube.com/watch?v=Vr2FLgmWCJA

Detiknews. (2021). Industri Musik Pasca-Pandemi: Interview with Anang Hermansyah [Webpage]. Retrieved 10 March 2021, from https://news.detik.com/kolom/d-5486946/industri-musik-pasca-pandemi

Habe, K., Biasutti, M., \& Kajtna, T. (2021). Wellbeing and flow in sports and music students during the COVID-19 pandemic. Thinking Skills and Creativity, 39, 100798. Retrieved from https://doi.org/10.1016/j.tsc.2021.100798

Hash, P. M. (2021). Remote learning in school bands during the covid-19 shutdown. Journal of Research in Music Education, 68(4), 381-397. Retrieved from https://doi.org/10.1177/0022429420967008

Hine, C. (2015). Ethnography for the internet. UK; USA: Bloomsbury Academic.

Jatmika, O. B. (2020). Faktor penunjang pertunjukan musik: Input, proses, dan output. Journal of Music Science, Technology, and Industry, 3(1), 79-90. Retrieved from https://doi.org/10.31091/jomsti.v3i1.966

Kemdikbud. (2020). Apresiasi pelaku budaya [Webpage]. Retrieved 10 March 2021, from https://apb.kemdikbud.go.id/

Kompas.com. (2021). UPDATE: Tambah 6.389, Jumlah Kasus Covid-19 di Indonesia 1.392.945 Orang Halaman all [Webpage]. Retrieved 10 March 2021, from https://nasional.kompas.com/read/2021/03/09/17215171/update-tambah-6389-jumlah-kasus-covid-19di-indonesia-1392945-orang

Kozinets, R. V. (2015). Netnography: Redefined. (M. Steele,Ed.) (2nd Ed). Los Angeles; London: SAGE Publications Ltd.

Kumparan. (2021). Foto: Presiden Jokowi Orang Pertama di Indonesia yang Divaksin Corona [Webpage]. Retrieved 10 March 2021, from https://kumparan.com/kumparannews/foto-presiden-jokowi-orangpertama-di-indonesia-yang-divaksin-corona-1uy9nMfSBQy 
Lehman, E. T. (2020). "Washing hands, reaching out" - popular music, digital leisure and touch during the covid-19 pandemic. Leisure Sciences, 0(0), 1-7. Retrieved from https://doi.org/10.1080/01490400.2020.1774013

Metro TV Jateng \& DIY. (2020). Konser drive in pertama di Indonesia digelar di Semarang [YouTube Channel]. Retrieved 9 March 2021, from https://www.youtube.com/watch?v=BYE1KCXGc50

Michael Mulyadi. (2020). Digital Performance! Manjur ga sih? - Michael HB Raditya dan Giovani Biga [YouTube Channel]. $\quad$ Retrieved $10 \quad$ March 2021, from https://www.youtube.com/watch?v=eoADYznaqeg

Parsons, C. (2020). Music and the internet in the age of covid-19. Early Music, 48(3), 403-405. Retrieved from https://doi.org/10.1093/em/caaa045

Postill, J. (2017). Studying culture from afar. In The routledge companion to digital ethnography (pp. 61-69). New York \& London: Routledge.

Riyan Hidayat. (2020). Webinar Candra Darusman bersama komite musik DKL: Mencari bentuk musik pasca pandemi [YouTube Channel]. Retrieved 9 March 2021, from https://www.youtube.com/watch?v=Mschm64kjb8

Sahid, S. (2020). What coronavirus has done to music industry and how they overcome it (SSRN Scholarly Paper No. ID 3590920). Retrieved 11 March 2021 from Rochester, NY: Social Science Research Network: $10.2139 /$ ssrn. 3590920

Savage, J. (2021). Teaching music in England today. International Journal of Music Education, 0255761420986213. Retrieved from https://doi.org/10.1177/0255761420986213

Septiyan, D. D. (2020). Perubahan budaya musik di tengah pandemi covid-19. Musikolastika: Jurnal Pertunjukan Dan Pendidikan Musik, 2(1), 31-38. Retrieved from https://doi.org/10.24036/musikolastika.v2i1.37

The Jakarta Post. (2020a). BREAKING: Jokowi announces Indonesia's first two confirmed COVID-19 cases [Webpage]. Retrieved 9 March 2021, from https://www.thejakartapost.com/news/2020/03/02/breakingjokowi-announces-indonesias-first-two-confirmed-covid-19-cases.html

The Jakarta Post. (2020b). Govt to enforce mandatory mask-wearing operation across Indonesia [Webpage]. Retrieved 10 March 2021, from https://www.thejakartapost.com/news/2020/09/10/govt-to-enforcemandatory-mask-wearing-operation-across-indonesia.html

Vance, D., Shah, P., \& Sataloff, R. T. (2021). Covid-19: Impact on the musician and returning to singing; A literature review. Journal of Voice, S0892199721000035. Retrieved from https://doi.org/10.1016/j.jvoice.2020.12.042

Vandenberg, F., Berghman, M., \& Schaap, J. (2021). The 'lonely raver': Music livestreams during COVID-19 as a hotline to collective consciousness? European Societies, 23(sup1), S141-S152. Retrieved from https://doi.org/10.1080/14616696.2020.1818271 